\title{
Review on History and Achievements of Triticale Breeding Status in Ethiopia
}

\author{
Mohammedsani Zakir ${ }^{1 *}$, Tegegn Belete ${ }^{2}$ \\ ${ }^{I}$ Ethiopian Institute of Agricultural Research \\ ${ }^{2}$ Jimma Agricultural Research Center P.O. Box: 192; Jimma, Ethiopia
}

*Corresponding Author: Mohammedsani Zakir, Ethiopian Institute of Agricultural Research

\begin{abstract}
Triticale is a crop developed by crossing wheat (Triticum turgidum or aestivum) with rye (Secale cereal). It combines yield potential and grain quality of wheat with the disease and environmental tolerance including adaptability to difficult soils, drought tolerance, cold hardiness, disease resistance and low-input requirements of rye. Triticale grains can be used for human food and livestock feed. Since the last century, triticale has received significant attention as a potential energy crop. The aim of a triticale breeding programs mainly focuses on the improvement of economic traits such as grain yield, biomass, nutritional factors, plant height, as well as traits such as early maturity and high grain volume weight. Intense breeding and selection have made very rapid genetic improvements in triticale seed quality. According to the reports of $M o A$, there are seven released varieties of triticale from different centers. The review goes through history of triticale breeding and major achievements of triticale breeding in Ethiopia.
\end{abstract}

Keywords: achievement, breeding, crossing, Ethiopia, triticale

\section{INTRODUCTION}

Triticale (Triticosecale, Wittmack), the first successful human made hybrid cereal grain, was deliberately produced by crossing wheat (Triticum) as female and rye (Secale) as a pollen source. Wheat yields and grain quality are better than rye. But rye has greater disease resistance and better tolerance to environmental stress. Triticale combines yield potential and grain quality of wheat with the disease and environmental tolerance including adaptability to difficult soils, drought tolerance, cold hardiness, disease resistance and low-input requirements of rye (FAO, 2004). Triticale is less susceptible to the common fungal diseases of cereals which make it suitable for use in rotations where stubble is retained (Jessup and Wright, 1991). Triticale can be grown in a wide range of agroecologies, up to $3000 \mathrm{~m}$. It requires an average of 500-600 mm rainfall, well distributed during the growing season. However, it can also perform well with as little as $350 \mathrm{~mm}$ of seasonal rainfall (Gobeze et al., 2007). It is adapted to a wide range of soils conditions including low fertility sands, shallow soils, acidic and sodic, very high and low PH. Triticale has more vigorous root system than wheat, barley or oats binding light soils and extracting more nutrients from the soil and its vigorous root system makes growing this plant attractive in low fertile soils, light soils and where a crop is being to better compete with weeds (Gobeze et al., 2007). Drought and frost tolerance are the primary advantages that triticale has over the other cereal crops and thus it reduces weather risk. Additionally, its yield advantage over wheat, barley, and other small grains is also great and it resists lodging better than wheat and barley (Gobeze et al., 2007). Triticale has demonstrated high yield potential even under marginal growing conditions and could a very attractive alternative for raising cereal production globally (FAO, 2004).

Modern triticale grain is an excellent feed grain for use in mixed poultry diets. Grain from modern triticale varieties has been reported to be comparable in energy value to other cereal grains for use in mixed diets of beef and dairy cattle, sheep, broilers and laying hens and pigs and its protein is well utilized (Myer, 2002). As a food grain, triticale has also been recognized as a hardy crop capable of helping combat world hunger. Triticale has potential in the production of bread and other food products such as pasta and breakfast cereals (Pen a, 2004). Triticale is suitable for producing a range of unleavened products such as cakes, cookies, biscuits, waffles, noodles, flour tortillas, and spaghetti 
(Skovmand et al., 1984). Triticale cultivars possessing improved grain shape and plumpness produce flour yields equal or closer to those of wheat (Saxena et al., 1992).

\section{LITERATURE REVIEW}

\subsection{History of Triticale Breeding}

Research workers soon realized that the primary triticales were autogamous and vigorous, but they were partially sterile and the kernels were shriveled. The first six lines of the octoploid triticale that Müntzing (1939) studied showed variability for characters such as vigour, pollen fertility, seed setting, grain shriveling, baking quality and winter hardiness. This variability was quickly used by breeders, who made crosses between the primary triticale and started breeding programs for the production of secondary triticale. The inconveniences of low fertility and excessive seed shriveling were partially overcome by selection within lines. However, the (1961) and others did not find that the selection of plants with the highest seed set was effective.

A much debated question that arose from the production of secondary triticale was that of the relationships between fertility, aneuploidy and the regularity of the meiosis. Vettel (1960), working with the Rimpau triticale and several mutants, found a negative correlation between the frequency of aneuploid descendants and the fertility of the mother plant. Pollen grains with aneuploid numbers rarely functioned and when they did so, the chromosome number only deviated by \pm 1 chromosome from the euploid number. Working with octoploid material showing very high chromosomal instability, Krolow (1962) was able to reduce the aneuploid frequency from $83.3 \%$ to only $60.6 \%$ by selecting the more fertile plants. Reselection within lines allowed him to reduce the aneuploid frequency to $40.3 \%$. In the same experiment, Krolow found a positive correlation between aneuploid frequency and sterility of the mother plant and between aneuploidy and reduction of tallness. Later experiments (Krolow, 1963) confirmed these results.

At the hexaploid level, Krolow (1966) found much lower figures for the frequency of aneuploidy. In the progeny of euploid plants with 42 chromosomes he found $7 \%$ aneuploids, mainly with 41 and 43 chromosomes. The progenies of these aneuploids showed a tendency to revert to the euploid number of 42 , as the average chromosome number in the progeny of 41-chromosome plants was 41.31 , and 42.53 in the progeny of 43 -chromosome plants. However, it is easy to show, using Krolow's figures, that in the absence of selection the total frequency of aneuploids tends to increase in such a population.

In crosses between hexaploid triticale it was possible to select, in the F3 generation, plants with good fertility, 42 chromosomes and a more stable meiosis than the parents of the cross (Krolow, 1969). It was suggested by Muntzing (1956) that some of the unfavorable characters of triticale could be due to the fact that it is an autogamous species resulting from the integration of the genotype of an autogamous wheat species with the genotype of an allogamous rye species. The genetic contribution of rye would be subject to inbreeding degeneration. He then suggested that inbred lines of rye selected for self-fertility or F1 hybrids between them be used for the production of triticales.

\subsection{Triticale Production in Ethiopia}

Triticale is adapted to a wide range of soil conditions ranging from sandy to clay soil types. It requires an average of 500-600mm rainfall, well distributed during the growing season.However, it can also perform well with as little as $350 \mathrm{~mm}$ of seasonal rainfall. Triticale was found that it increased farmer's net benefit compared to wheat and barley in Farta District of Amhara Region (Mesfin et al., 2012). In Ethiopia, the grain is used for human food, while the straw is used for animal feed, roof thatching, and bedding. Even though its food quality is less than wheat and barley, the local community at South Gondar and other triticale growing environments utilize it in form of injera, flat bread, roasted grain and boiled grain. To improve the food quality of triticale they usually used blending with other cereal flour such as wheat, tef, and barley ( Muluken et al., 2014).

According to Central Statistic Agency (CSA, 2016) there was not solely an exact indication of area coverage and production of triticale report generally in Ethiopia and particularly in Amhara region, but there are improved varieties developed and released for production for different agro ecologies of Ethiopia. Triticale is not well established and not a common crop in Wag-Lasta wheat and barley growing marginal areas, but production is started in some marginal highland areas of Lasta (personal communication). 


\subsection{Major Achievements in Triticale Breeding}

The last four decades of research on triticale initiated by CIMMYT in association with National Agricultural Research Systems (NARS) around the world have resulted in significant improvements of triticale crop. Triticale today is an international crop grown in more than 28 countries with the number of countries and the acreage under triticale production increasing. In 2003, triticale occupied nearly 3 million ha worldwide, compared to about 1 million ha in 1988 (Varughese et al., 1996).

\subsubsection{Yield Increase}

Major success in increasing the triticale yield has been attributed to research and development conducted at CIMMYT, Mexico. Under near optimal conditions at Ciudad Obrego'n, Mexico, a comparison of maximum-yield trials of triticale developed at CIMMYT revealed an average increase of $1.5 \%$ per year (Sayre et al., 1996). The genetic gain in yield potential was mainly due to a substantial increase in harvest index, grains $/ \mathrm{m}^{2}$, spikes $/ \mathrm{m}^{2}$, test weight and a decrease in plant height. Lodging resistance in triticale has been successfully introgressed using the dwarfing genes from both Triticum and Secale species. This has resulted in a decrease of up to $20 \mathrm{~cm}$ in plant height and increasing yield as the semi-dwarf cultivars are high yielding and more responsive to inputs. In 1968, at Ciudad Obregon, in northwest Mexico, the highest yielding triticale line produced $2.4 \mathrm{t} / \mathrm{ha}$. Today, CIMMYT has released high yielding spring triticale lines (Pollmer-2) which have surpassed the 10 t/ha yield barrier under optimum production conditions (Hede, 2000). According to the reports of MoA, there are seven released varieties of triticale from different centers (Table 1).

Table1. Released varieties of triticale in Ethiopia

\begin{tabular}{|c|c|c|c|c|c|}
\hline Variety name & $\begin{array}{c}\text { Year of } \\
\text { release }\end{array}$ & $\begin{array}{c}\text { Days to } \\
\text { maturity }\end{array}$ & $\begin{array}{c}\text { Altitude } \\
(\mathbf{m . a . s . l})\end{array}$ & $\begin{array}{c}\text { Released } \\
\text { Center }\end{array}$ & $\begin{array}{c}\text { Grain yield } \\
\text { (Qt/ha) }\end{array}$ \\
\hline TT2 (DIL FERAR) & 2007 & 136 & $1800-2600$ & KARC & $24-44$ \\
\hline TT14 (LOGAW SHIBO & 2007 & 135 & $1800-2600$ & KARC & $24-44$ \\
\hline Zenkatie (TCL 59) & 2013 & 146 & $2300-2700$ & Adet ARC & $37.5-63.9$ \\
\hline Abdissa (TCL -76) & 2013 & $127-154$ & $1800-2700$ & BARC/OARI & $44-62$ \\
\hline Moti (TCL -61) & 2013 & 141 & $1800-2700$ & BARC/OARI & $40-53$ \\
\hline Dersolign (ADTR-085) & 2012 & 141 & $>2400$ & Adet ARC & $31.61-58.83$ \\
\hline Logashibo & 2007 & 135 & $1800-2600$ & KARC & 44.24 \\
\hline Minet & 2002 & 143 & 2600 & Adet ARC & 37.0 \\
\hline
\end{tabular}

BARC $=$ Bako Agricultural Research Center, KARC $=$ Kulumisa Agricultural Research Center, OARI = Oromia Agricultural Research Institute, ARC=Agricultural Research Center

Source: MoA, plant variety release, protection and seed quality center directorate

\subsubsection{Adaptation}

Development of triticale cultivars expressing high and stable yields as a result of input efficiency and responsiveness, and resistance to a wide range of biotic and abiotic stresses, has resulted in increasing the acreage under triticale worldwide. Early maturity, a typical characteristic of modern triticale, allows escape from terminal developmental stresses, such as heat or frost, in highly productive environments, such as the irrigated subtropics and Mediterranean climates, which has contributed to triticale acceptance by farmers. Substituted or octoploid triticale attracted additional interest because of its $\mathrm{R}$ rye genome associated to high uptake of nutrients and $\mathrm{D}$ wheat genome associated to high efficiency of their metabolism (Osborne and Rengel, 2002).

Modern triticale cultivars have good tolerance of aluminum, which becomes increasingly available in acid soil conditions, and have good efficiency for accessing major nutrient (phosphorus) and trace elements (manganese, copper, zinc) in alkaline soils where these elements tend to become poorly available. Many triticale cultivars have good water-logging tolerance, tolerance to periods of drought, and some Polish material has been demonstrated to have good tolerance to salinity (Koebner and Martin, 1996). Under marginal land conditions, where abiotic stresses related to environment (drought or temperature extremes) and soil conditions (extreme PH levels, salinity, toxicity, or deficiency of elements) are the limiting factors for grain production, modern triticale cultivars have consistently shown its advantages and has outperformed the existing cultivated cereal crops (Mergoum et al., 2004). 


\subsubsection{Enhanced Quality}

Triticale breeding programs worldwide including CIMMYT have emphasized improving the product quality and developing triticale cultivars for specific end uses. The most significant improvement was achieved for plumper grain. The test weight of the best Armadillo selections in 1970 at CIMMYT was $73.7 \mathrm{~kg} / \mathrm{ha}$ compared to $65.8 \mathrm{~kg} / \mathrm{ha}$ of the best line in 1968 (Zillinsky and Borlaug, 1971). Substantial progress has continued to improve test weight, and some modern triticale can reach $80 \mathrm{~kg} / \mathrm{ha}$ under favorable environmental conditions (Mergoum et al., 2004). Since 1990, due to specific end use and market requirements, more emphasis has been given to developing triticale for specific end uses, such as milling and baking purposes, feed grain, dual purpose (forage and grain) and grazing types. Variability present in the triticale germplasm for pre-harvest sprouting and gluten quality has been exploited by breeders to develop cultivars with enhanced quality and sprouting resistance which has improved the bread-making qualities of triticale grain.

In general, winter triticale produces higher forage biomass than spring types. Therefore, their use for forage (grazing), cut forage, silage and grain or hay has been improved through the release of several forage specific cultivars. In addition, in many countries cereal straw is a major feed source for animals and in some years can have greater value than grain. Under arid and semiarid conditions, triticale has been shown consistently to produce higher straw yields than wheat and barley (Mergoum et al., 1992).

\subsubsection{Biotic Resistance}

Initially, biotic stresses did not appear to be a serious constraint to triticale production; however, as triticale acreage increased, most wheat and rye diseases started to infect triticale (Singh and Saari, 1991). In comparison with wheat, triticale appears to have good resistance to several common wheat diseases and pests including rusts (Puccinia sp.), Septoria complex, smuts (Ustilago and Urocystis sp.), bunts (Tilletia sp.), powdery mildew (Blumeria graminis), cereal cyst nematode (Heterodera avenae), and Hessian fly (Mayetiola destructor). It also resists virus diseases, such as barley yellow dwarf, wheat-streak mosaic, barleystripe mosaic, and brome mosaic (Varughese et al., 1996). However, it gets disease in common with other cereals, but there is considerable varietal variation in terms of disease resistance. Triticale has relatively greater susceptibility than wheat to diseases such as spot blotch (Bipolaris sorokiniana), scab (Fusarium sp.), and ergot (Claviceps purpurea) and bacterial diseases caused by Xanthomonas sp. and Pseudomonas sp., which preclude the immediate commercial introduction of triticale in those areas where wheat is otherwise better adapted (e.g. Zambia and Brazil) (Skovmand et al., 1984).

However, its susceptibility in the past was linked to problems with floret sterility and ergot is not seen as a major problem in current varieties. The reaction of triticale to many diseases and pests meets the expectations of a combined resistance found in the two parental species. The disease and insect resistance reactions of one or the other of the parents is reflected in triticale progeny or the reaction of triticale is intermediate between that of wheat and rye, as in the case of take all (Gaeumannomyces graminis) and Russian wheat aphid (Diuraphis noxia). There is some evidence that triticale varieties vary in their resistance depending on the number of rye-genetic material (chromosomes) present with varieties that have a greater number of rye chromosomes having greater resistance to take all (Wallwork, 1989).

\section{SUMMARY AND CONCLUSION}

Triticale use for forage (grazing), cut forage, silage and grain or hay has been improved through the release of several forage-specific cultivars for livestock production because; under arid and semiarid conditions triticale has been shown consistently to produce higher straw yields than wheat and barley. The considerable variability present in triticale germplasm for different diseases, pest and adaptability to various environments was being exploited by breeders to develop durable resistant and adaptable cultivar which has resulted in wide-scale production of triticale worldwide

\section{REFERENCES}

[1] Aufhammer, G., Schneider, R., Fischbeck, G., 1961. Ergebnisse Von Versuchen Zur Verbesserung Der Fertilitat Von Weizen-Roggen-Bastarden (Triticale). Zeitschrift Fur Pflanzenzuchtung-Journal of Plant Breeding, 45(4): 212.

[2] Central Statistic Agency (CSA), 2016. Agriculture sample survey. Report on area and production for major crops (Statistical Bulletin 532CSA). Ethiopia: Addis Ababa. 
[3] Food and Agriculture Organization (FAO), 2004. Triticale improvement and production. In Mohamed \& H. Gomez-Macpherson (Eds.). FAO Plant Production and protection paper 179.

[4] Gobeze, L., Legese, H., Daniel, M., 2007. Effect of land preparation methods and spacing in growth and yield of cassava. Proceedings of African Society of Crop Sciences, pp.68-72.

[5] Hede, A.R., 2000. A new approach to Triticale improvement. Available at http://www.cimmyt. org.

[6] Jessup, R.S. and Wright, R.C., 1991. New crops: Agronomy and potential of alternative crop species, Inkata Press. pp 175-182.

[7] Koebner, R.M.D. and Martin, P.K., 1996. High levels of salt tolerance revealed in triticale. In: H. GuidesPinto et al., eds. Proc. 3rd Int. Triticale Symp., June 1994, Lisbon, Portugal, pp. 429- 436.

[8] Krolow, 1969. Cytologische Untersuchungen an Kreuzungen zwischen 8x und 6x Triticale. I. Untersuchungen an den Eltern, an der FI und der Fz. - Ibid. 62: 241-271.

[9] Krolow, K. D., 1966. Aneuploidie und Fertilitat bei amphidiploiden Weizen-Roggen-Bastarden (Triticale). III. Aneuploidie, Fertilitas- und Halmlangenuntersuchungen an hexaploiden Triticale-Stammen. Z. Pflanzenzuchtg. 55: 105- 138.

[10] Krolow, K.D., 1962. Aneuploidie Und Fertilitat Bei Amphidiploiden Weizen-Roggen-Bastarden (Triticale). 1. Aneuploidie Und Selektion Auf Fertilitat Bei Oktoploiden Triticale-Formen. Zeitschrift Fur Pflanzenzuchtung-journal of plant breeding, 48(2):177.

[11] Krolow, K.D., 1963. Aneuploidie Und Fertilitat Bei Amphidiploiden Weizen-Roggen-Bastarden (Triticale). 2. Aneuploidie-Und Fertilitatsuntersuchungen an einer Oktoploiden Triticale-Form mit Starker Abregulierungstendenz. Zeitschrift Fur Pflanzenzuchtung-journal of plant breeding, 49(3):210

[12] Mergoum, M., Pfeiffer, W.H., Pen a, R.J., Ammar, K. and Rajaram, S., 2004. Triticale crop improvement: the CIMMYT programme. In: Mergoum, M. and Go 'mez-Macpherson H. (eds.). Triticale improvement and production. FAO Plant Production and Protection Paper No. 179. Food and Agriculture Organization of United Nations, Rome. pp. 11-26.

[13] Mergoum, M., Ryan, J. and Shroyer, J.P., 1992. Triticale in Morocco: potential for adoption in the semiarid cereal zone. J. Nat. Res. Life Sci. Edu. 21:137-141.

[14] Mesfin, A., Legesse, B., Ph.D., Zerfu, E., Ph.D., 2012. Analysis of economic impacts of triticale (XTriticosecale Wittmack) adoption: The case of Farta Wereda, Ethiopia. Ethiopia: Bahir Dare and Harmaya University.

[15] Muluken, B., Wondale, L., Gashu, K., Sharie, G., Teshager, A., \& Alemneh, M., 2014. Multi-environment performance evaluation of triticale (X Triticosecale Wittmack) genotypes in north-western, Ethiopia. In T. Tadesse \& Y. Merene (Eds.), 2014. Proceeding of the 6thand 7thAnnual Regional Conference on Completed Crops Research Activities. Bahir Dar, Ethiopia: Amhara Agricultural Research Institute.

[16] Muntzing, 1956. Cytogenetic studies in ryewheat (Tnticale). Proc. mt. Genet. Symp. 1956: 51-56.

[17] Müntzing, A., 1939. Studies on the properties and the ways of production of rye-wheat amphidiploids. Hereditas, 25(4):387-430.

[18] Myer, R.O., 2002. Triticale grain in young pig diets. In: Proc. Fifth Internat'l Triticale Symposium. Vol. I. Plant Breeding and Acclimatization Inst., Radzikow, Poland. p 272.

[19] Osborne, L.D. and Rengel, Z.,2002. Screening cereals for genotypic variation in efficiency of phosphorus uptake and utilization. Aust. J. Agric. Res. 53:295-303.

[20] Pen a, R.J.,2004. Food uses of triticale. In: Mergoum, M. and Go 'mez-Macpherson H. (eds.). Triticale improvement and production. FAO Plant Production and Protection Paper No. 179. Food and Agriculture Organization of United Nations, Rome. Pp.37-48.

[21] Saxena, A.K., Bakhshi, A.K., Sehgal, K.L., Sandha, G.S., 1992. Effect of grain texture on various milling and end use properties of newly bred advanced triticales (wheat $\mathrm{x}$ rye) lines. J. Food Sci. Tech. 29:14-16.

[22] Sayre, K., Pfeiffer, W.H., Mergoum, M., 1996. Triticale: grain potential and response to input management levels. In: Triticale Topics. Int. Ed. No. 14:9-16.

[23] Singh, R.P. and Saari, E.E., 1991. Biotic stresses in triticale. In: Proc. 2nd Int. Triticale Symp., Passo Fundo, Rio Grande do Sul, Brazil, October 1-5, 1990. Mexico, DF, CIMMYT. Pp.171-177.

[24] Skovmand, B., Fox, P.N. and Villareal, R.L., 1984. Triticale in commercial agriculture: progress and promise. Adv. Agron. 37:1-45.

[25] Varughese, G., Pfeiffer, W.H. and Pen a, R.J., 1996. Triticale (Part 1): a successful alternative crop. Cer. Foods World 41:474-482.

[26] Vettel, F., 1960. Mutation experiments on wheat-rye hybrids (Triticale). III. Induction of mutation in Triticale Meister and Triticale 8324. Züchter, 30:313-29 
[27] Wallwork, H., 1989. Screening for resistance to take-all in wheat, triticale and wheat-triticale hybrid lines. Euphytica 40:103-110

[28] Zillinsky, F.J. and Borlaug, N., 1971. Progress in developing triticale as an economic crop. CIMMYT Res. Bull. 17. Mexico, DF, CIMMYT. pp27

Citation: Mohammedsani Zakir, Tegegn Belete, "Review on History and Achievements of Triticale Breeding Status in Ethiopia” International Journal of Research Studies in Agricultural Sciences (IJRSAS), 2019; 5(9), pp. 8-13, http://dx.doi.org/10.20431/2454-6224.0509002

Copyright: (C) 2019 Authors. This is an open-access article distributed under the terms of the Creative Commons Attribution License, which permits unrestricted use, distribution, and reproduction in any medium, provided the original author and source are credited. 